\title{
Obce przepisy wymuszające swoje zastosowanie Glosa do wyroku Trybunału Sprawiedliwości Unii Furopejskiej z dnia 18 października 2016 r. w sprawie C-135/15 Republika Grecji przeciwko Grigoriosowi Nikiforidisowi*
}

\begin{abstract}
This commentary examines the judgement of the CJEU of 18 October 2016 in case C-135/15 Republik Griechenland v. Grigorios Nikiforidis. The judgement in question concerns the issue of treatment of foreign overriding mandatory provisions under the Article 9(3) of Regulation No 593/2008. This topic is the subject to a great deal of controversy and academic discussion. The ECJ concluded that the mentioned provision must be interpreted as precluding overriding mandatory provisions other than those of the State of the forum or of the State where the obligations arising out of the contract have to be or have been performed from being applied, as legal rules, by the court of the forum, but as not precluding it from taking such other overriding mandatory provisions into account as matters of fact in so far as this is provided for by the national law that is applicable to the contract pursuant to the Regulation. This interpretation is not affected by the principle of sincere cooperation laid down in Article 4(3) TEU. In this respect the judgement of CJEU brings significant clarification on the question, whether a court of the forum can have regard to foreign overriding mandatory provisions, which do not belong to the legal system of the country of performance of the contract on the level of the applicable substantive law. However, there are still questions arising under Article 9(3) of Rome I Regulation, which need to be clarified.
\end{abstract}

Keywords: conflict of law rules relating to contractual obligations, Article 9 (3) Rome I Regulation, foreign overriding mandatory provisions, substantive law level consideration as a matter of fact

a) Dr,LL.M.(Köln)ZakładPrawaPrywatnegoMiędzynarodowego,UniwersytetGdański.

* ECLI:EU:C:2016:774. 


\section{Uwagi wprowadzające}

W komentowanym wyroku Trybunał dokonał wykładni art. 9 ust. 3 rozporządzenia $\mathrm{nr}$ 593/2008 Rzym $\mathrm{I}^{1}$ dotyczącego stosowania obcych przepisów wymuszających swoje zastosowanie. Interpretacja tego przepisu jest przedmiotem sporów w doktrynie ${ }^{2}$. Trybunał wyjaśnił watpliwości związane z zagadnieniem dopuszczalności stosowania takich przepisów przez sąd państwa forum. Problematyka obcych przepisów wymuszajacych swoje zastosowanie jest przedmiotem licznych rozważań i kontrowersji zarówno w polskiej, jak i obcej doktrynie prawa prywatnego międzynarodowego ${ }^{3}$. Problematyka ta jest obecna również $\mathrm{w}$ orzecznictwie,

${ }^{1}$ Dz.U. UE L 177, s. 6 i n. [dalej: rozporządzenie Rzym I].

${ }^{2}$ Zob. m.in. A. Bonomi: Article 9. In: ECPIL Commentary. Rome I Regulation, ed. U. Magnus, P. Mankowski, Köln 2017, s. 639 i nast. M. Czepelak: Międzynarodowe prawo zobowiazań Unii Europejskiej, Wraszawa 2012, s. 486, 490; R. Freitag: Die kollisionsrechtliche Behandlung ausländischer Eingriffsnormen nach Art. 9 Abs. 3 Rom-I-VO. „Praxis des Internationalen Privat- und Verfahrensrechts” [dalej: IPrax 2009] H. 2, s. 109 i nast.; P. Hauser: Eingriffsnormen on der Rom-I-Verordnung, Tübingen 2012, s. 52 i nast.; M. Hellner: Third Country Overriding Mandatory Provisions in the Rome I Regulation: Old Wine in New Bolltes? "Journal of Private International Law” [dalej: JPIL] 2009), Vol. 5, s. 447 i nast.; A. Helmer: Die Methodik der „Eingriffsnorm” im modernen Kollisionsrecht, Tübingen 2019, s. 46 i nast.; A. Kohler: Eingriffsnormen - Der „Unfertige Teil” des europäischen IPR, Tübingen 2013, s. 103 i nast.; P. Mankowski: Drittstaatliche Embargonormen, Außenpolitik im IPR, Berücksichtigung von Fakten statt Normen: Art. 9 Abs. 3 Rom I-VO im praktischen Fall. IPrax 2016, H. 5, s. 485 i nast.; D. Martiny: Art. 9 Rom I-VO. In: Münchener Kommentar zum BGB. Bd 10: Internationales Privatrecht. Europäisches Kollisionsrecht. Einführungsgesetz zum Bürgerlichen Gesetzbuche (Art. 1-24). Hrsg. J v. Hein, München 2015, s. 554 i nast.; W.-H. Roth: Drittstaatliche Eingriffsnormen und Rom I-Verordnung. IPRax 2018, H. 2, s. 181-182 i powołana tam literatura; M. Thorn: Forumfremde Eingriffsnormen und Außenpolitik im IPR. In: IPrax 2019, H. 4, s. 301 i nast.; M. Tomaszew ski: Komentarz do art. 8. W: Prawo prywatne międzynarodowe. Komentarz. Red. J. Poczobut, Warszawa 2017, s. 245; M.A. Zacharia siewicz: Objaśnienia do art. 9 Rzym I. W: Prawo prywatne międzynarodowe. Komentarz. Red. M. Pazdan, Warszawa 2018, s. 714-717; M.A. Zachariasiewicz: Przepisy wymuszajace swoje zastosowanie. W: System Prawa Prywatnego. T. 20A: Prawo prywatne międzynarodowe. Red. M. Pazdan, Warszawa 2014, s. 466 - 469 i powołana tam literatura.

${ }^{3}$ Zob. m.in. K. Anderegg: Ausländische Eingriffsnormen im internationalen Vertragsrecht, Tübingen 1989, s. 7 i nast.; E. Benzberg: Die Behandlung ausländischer Eingriffsnormen im internationalen Privatrecht, Jena 2008, s. 39 i nast.; B. Fuchs: Statut kontraktowy a przepisy wymuszajace swoje zastosowanie, Katowice 2003, s. 151 i nast.; R. Lehmann: Eingriffsnormen dritter Staaten und die deutsche IPR-Reform. „Zeitschrift für Rechtspolitik” 1987, H. 9, s. 319 i nast.; M. Mataczyński: Przepisy wymuszajace swoje zastosowanie $w$ prawie prywatnym międzynarodowym, Kraków 2005, s. 156 i nast.; Idem: Obce przepisy wymuszajace swoje zastosowanie. Rozważa- 
aczkolwiek jak trafnie zauważa rzecznik generalny M. Szpunar w swojej opinii $\mathrm{w}$ tej samej sprawie ${ }^{4}$, jest ono stosukowo nieliczne ${ }^{5}$. Rozstrzygnięcie Trybunału poniekąd wypełnia tę orzeczniczą lukę i jednocześnie w duchu teorii faktu wyjaśnia wątpliwości co do sposobu zastosowania rzeczonych przepisów na gruncie rozporządzenia Rzym I. Komentowany wyrok dowodzi równocześnie, że ta sporna w doktrynie problematyka jest doniosła nie tylko z teoretycznego punktu widzenia, ale również ma znaczenie praktyczne. Podkreślić wszakże należy, że komentowane orzeczenie dotyczy wyłącznie obcych przepisów wymuszających swoje zastosowanie $\mathrm{w}$ odniesieniu do umów objętych zakresem zastosowania rozporządzenia Rzym I. Niemniej mając na uwadze prounijną wykładnię prawa krajowego dokonana w nim interpretacja powinna stanowić cenzurę również w odniesieniu do mających ogólny charakter krajowych regulacji odnoszących się do obcych przepisów wymuszających swoje zastosowanie, które z natury rzeczy odnosić się będą w szczególności również do sfery umów, w tym nieobjętych zakresem zastosowania rozporządzenia Rzym I. O ile autorowi wiadomo, komentowane orzeczenie nie było dotychczas przedmiotem glos w polskim piśmiennictwie ${ }^{6}$.

W tym miejscu należy zwrócić uwagę na dwie kwestie dotyczące stosowania obcych przepisów wymuszających swoje zastosowanie. Po pierwsze, jeżeli przepisy takie zostały ustanowione przez prawo państwa, które jest właściwe dla danego stosunku podlegajacego ocenie, to kwestia dopuszczalności ich stosowania w ogóle się nie pojawia, albowiem przepisy takie stanowią wówczas po prostu część systemu prawnego,

nia na tle art. 7 konwencji rzymskiej oraz orzecznictwa sqdów niemieckich. „Kwartalnik Prawa Prywatnego" [dalej: KPP] 2001, z. 2, s. 375 i nast.; I. Pötting: Die Beachtung forumsfremder Eingriffsnormen bei vertraglichen Schulsverhältnissen nach europäischem und Schweizer IPR, Frankfurt am Main, Berlin, Bern, Wien, New York 2012, s. 5 i n.; M. Tomaszewski: Komentarz do art. 8, s. 241 i nast.; M.A. Zachariasiewicz: Objaśnienia do art. 8 Pr.PrywM. W: Prawo prywatne międzynarodowe. Komentarz. Red. M. Pazdan, Warszawa 2018, s. 164 i nast.; M.A. Zachariasiewicz: Przepisy..., s. 454 i nast. oraz powołana tam literatura. Zob. także literaturę powołaną w przypisie 3.

${ }^{4}$ Opinia z dnia 20 kwietnia 2016 r., ECLI:EU:C:2016:281 [dalej: opinia]. Por. pkt 1 opinii.

${ }^{5}$ Zob. przykładowo wyroki niemieckiego: BGH z dnia 21 grudnia 1960 r., VIII ZR 1/60. „Neue Juristische Wochenschrift” [dalej: NJW] 1961, H. 18 s. 822 i nast.; z dnia 22 czerwca 1972 r., II ZR 113/70. NJW 1972, H. 35, s. 1575 i nast.; z dnia 29 września 1977 r., III ZR 164/75, NJW 1977, H. 51, s. 2356 i nast.; Więcej co do orzecznictwa w tym względzie zob. K. Anderegg: Ausländische..., s. 9 i nast.; P. Mankowski: Drittstaatliche..., s. 485 i nast.; M. Mataczyński: Przepisy..., s. 161 i nast.; Idem: Obce..., s. 387 i nast.; M. Thorn: Forumfremde..., s. 301 i nast.

${ }^{6} \mathrm{~W}$ obcym piśmiennictwie zob. A. Kronenberg: Foreign overriding mandatory provisions under the regulation (EC) No 593/2008 (Rome I Regulation). Judgement of the European Court of Justice of 18 october 2016, Case C-135/15. „Caudernos de Derecho Transnacional" 2018, Vol. 10, No 2, s. 873 i nast. 
w oparciu o który należy wydać rozstrzygnięcie ${ }^{7}$. Wyłączona jest wówczas właściwie konieczność odrębnego ustalania tudzież przyznawania określonym przepisom tego państwa charakteru wymuszającego swoje zastosowanie. Nie ma przy tym znaczenia, czy prawem tym jest prawo państwa sądu, który rozpoznaje daną sprawę, czy inny system prawny, którym może być również porządek prawny państwa, w którym umowa nie jest wykonywana. Po drugie, chodzić może o sytuację, w której prawem właściwym dla danego stosunku prawnego jest prawo państwa sądu rozpoznającego daną sprawę tudzież prawo innego państwa, w rachubę zaś wchodzi dopuszczalność stosowania przepisów wymuszających swoje zastosowanie ustanowione przez państwo trzecie. Ta kwestia jest właśnie przedmiotem wątpliwości niemieckiego Federalnego Sądu Pracy, które wyjaśnić miał Trybunał w przedmiotowej sprawie.

\section{Stan faktyczny i pytania prejudycjalne}

Stan faktyczny leżący u podstaw rozstrzygnięcia Trybunału przedstawiał się następująco. Skarżący w postępowaniu głównym, Grigorios Nikiforidis, był nauczycielem zatrudnionym w prowadzonej przez Republikę Grecką szkole podstawowej znajdującej się w Niemczech, w Norymberdze. Na początku 2010 r., w związku z kryzysem zadłużenia, parlament grecki przyją ustawy $\mathrm{nr} 3833 / 2010^{8}$ i $\mathrm{nr} 3845 / 2010^{9}$ majace na celu obniżenie wydatków publicznych. Ustawy te obniżyły wynagrodzenia pracowników sektora publicznego, w tym nauczycieli zatrudnionych w szkołach państwowych. Powołując się na te ustawy, Republika Grecka obniżyła wynagrodzenie G. Nikiforidisa. Grigorios Nikiforidis wytoczył przed sądami niemieckimi powództwo przeciwko swojemu pracodawcy, Republice Greckiej, reprezentowanej przez ministerstwo ds. edukacji i wyznań, w związku z rozliczeniem z tytułu wynagrodzenia za pracę

${ }^{7}$ Por. B. Fuchs: Statut..., s. 73; H.-P. Mansel: Eingriffsnormen im internationalen Sachenrecht. In: Privat- und Wirtschaftsrecht in Europa. Festschrift für Wulf-Hennig Roth zum 70. Geburtstag. Hrsg. T. Ackermann, J. Köndgen, Munchen 2015, s. 378.

${ }^{8}$ Ustawa nr 3833/2010 w sprawie pilnych środków mających na celu zwalczanie kryzysu finansów państwa, Dziennik Rządowy Republiki Greckiej, cz. I, dziennik nr 40 $\mathrm{z}$ dnia 15 marca $2010 \mathrm{r}$.

${ }^{9}$ Ustawa nr 3845/2010 w sprawie środków dla stosowania mechanizmu wsparcia dla greckiej gospodarki ze strony państw członkowskich strefy euro i Międzynarodowego Funduszu Walutowego, Dziennik Rządowy Republiki Grecji, cz. I, dziennik nr 65 z dnia 6 maja 2010 r. 
za okres od października 2010 r. do grudnia 2012 r. Wyrokiem z dnia 30 marca 2012 r. są pracy w Norymberdze oddalił powództwo, wskazując na immunitet państwa greckiego. Wyrokiem z dnia 25 września 2013 r. krajowy sąd pracy w Norymberdze (sad drugiej instancji) uchylił wspomniany wyrok i orzekł na korzyść G. Nikiforidisa. Od tego rozstrzygnięcia Republika Grecka wniosła skargę kasacyjną do niemieckiego Federalnego Sądu Pracy. W postępowaniu kasacyjnym Federalny Sąd Pracy ustalił, że stosunek pracy między stronami ma charakter prywatnoprawny i nie wchodzi w zakres immunitetu państwa greckiego. Potwierdził on także jurysdykcję sąów niemieckich na podstawie art. 18 ust. 1 oraz art. 19 pkt 2 lit. a) rozporządzenia Rady (WE) nr 44/2001 z dnia 22 grudnia 2000 r. w sprawie jurysdykcji i uznawania orzeczeń sadowych oraz ich wykonywania w sprawach cywilnych i handlowych ${ }^{10}$. Ponadto sąd ten ustalił, że stosunek pracy podlega prawu niemieckiemu, w świetle którego obniżenie wynagrodzenia wymaga zmiany umowy o pracę lub wypowiedzenia zmieniającego. $\mathrm{Z}$ tego też względu istotne znaczenie dla rozstrzygnięcia sporu ma to, czy do stosunku pracy między stronami sąd odsyłajaccy może zastosować przepisy greckich ustaw nr 3833/2010 i nr 3845/2010 lub w jakikolwiek inny sposób przyznać skuteczność tym przepisom. W tych okolicznościach federalny sąd pracy postanowił zawiesić postępowanie i zwrócić się do Trybunału w trybie prejudycjalnym o wyjaśnienie powstałych watpliwości interpretacyjnych, a w szczególności o to, czy art. 9 ust. 3 rozporządzenia Rzym I wyłacza jedynie bezpośrednie stosowanie wymuszających swoje zastosowanie przepisów państwa trzeciego, w którym nie ma nastąpić lub nie nastąpiło wykonanie zobowiązań wynikających z umowy, czy też i pośrednie ich uwzględnianie w prawie państwa, któremu podlega umowa oraz czy ustanowiona w art. 4 ust. 3 Traktatu o Unii Europejskiej ${ }^{11}$ zasada lojalnej współpracy ma znaczenie prawne dla decyzji sądów krajowych o bezpośrednim lub pośrednim stosowaniu wymuszających swoje zastosowanie przepisów innego państwa członkowskiego? ${ }^{12}$.

${ }^{10}$ Dz.U. UE L 12, s. $1 \mathrm{n}$. Rozporządzenie to zostało zastapione obowiązujacym obecnie rozporządzeniem Parlamentu Europejskiego i Rady (UE) nr 1215/2012 z dnia 12 grudnia 2012 r. w sprawie jurysdykcji i uznawania orzeczeń sądowych oraz ich wykonywania w sprawach cywilnych i handlowych, Dz. U. UE L 352, s. 1 i n.

${ }^{11}$ Dz.U. UE z 2012, C 326, s. 1 i n. - wersja skonsolidowana, dalej „TUE”

${ }^{12} \mathrm{~W}$ pierwszym pytaniu sąd odsyłajacy zwrócił się do Trybunału ponadto o wyjaśnienie czasowego zakresu zastosowania rozporządzenia Rzym I. Tak kwestia nie stanowi przedmiotu analizy w niniejszej glosie jako nieistotna w kontekście samej dopuszczalności stosowania obcych przepisów wymuszających zastosowanie, których dotyczy spór. 


\section{Rozstrzygnięcie Trybunału}

Udzielając odpowiedzi na zadane przez sąd odsyłający pytania, Trybunał jednoznacznie opowiedział się za teorią faktu ${ }^{13}$. Trybunał stwierdził, że art. 9 ust. 3 rozporządzenia Rzym I należy interpretować w ten sposób, że wyklucza on, by przepisy wymuszające swoje zastosowanie inne niż tego rodzaju przepisy państwa sądu lub państwa, w którym ma nastąić lub nastąpiło wykonanie zobowiązań wynikających z umowy, mogły zostać zastosowane jako normy prawne przez sad orzekajacy, ale nie stoi na przeszkodzie uwzględnieniu przez sąd orzekający takich innych przepisów wymuszajacych swoje zastosowanie jako okoliczności faktycznej w zakresie, w jakim przewiduje to prawo krajowe właściwe dla umowy na mocy przepisów tego rozporządzenia. Oznacza to, że rzeczone przepisy moga być brane pod uwagę przez sądy państwa forum wyłacznie jako okoliczność faktyczna na podstawie i w zakresie, w jakim zezwala na to statut kontraktowy (lex contractus) wyznaczony zgodnie z rozporządzeniem Rzym I w drodze wyboru prawa lub przez łączniki obiektywne. W ocenie Trybunału wykładni tej nie podważa ustanowiona w art. 4 ust. 3 TUE $^{14}$ zasada lojalnej współpracy. Wykładnia dokonana przez Trybunał wyłącza zatem ewentualnie przewidziana w prawie krajowym możliwość bezpośredniego uwzględniania przepisów wymuszajacych swoje zastosowanie państwa trzeciego ${ }^{15}$. Niemniej wyznacza on również kierunek dla interpretacji stosownych przepisów prawa krajowego w odniesieniu do umów nieobjętych zakresem zastosowania rozporządzenia Rzym I.

\section{Przesłanki dopuszczenia do głosu przepisów wymuszających swoje zastosowanie państwa trzeciego}

Za dopuszczalnością stosowania przepisów wymuszających swoje zastosowanie należących do państwa trzeciego przemawia wiele przekonu-

${ }^{13}$ Co do tej teorii szerzej zob. M.A. Zachariasiewicz: Objaśnienia do art. 8 $\operatorname{PrPrywM}$, s. 158.

${ }^{14}$ Traktato Unii Europejskiej (wersja skonsolidowana 2016), Dz.U. C 202, z 7.06.2016r.

${ }_{15}$ Por. M.A. Zachariasiewicz: Objaśnienia do art. 9 Rzym I, s. 717. 
jących względów ${ }^{16}$. Dopuszczenie do głosu w konkretnej sprawie przepisów wymuszających swoje zastosowanie należących do państwa trzeciego umożliwia wydanie sprawiedliwego rozstrzygnięcia uwzględniającego słuszny interes tego państwa, dzięki czemu można usunąć ewentualne przeszkody $\mathrm{w}$ odniesieniu do uznawania lub wykonywania orzeczenia w tym państwie ${ }^{17}$. Możliwość uwzględnienia przepisów wymuszających swoje zastosowanie państwa trzeciego ogranicza negatywne skutki forum shopping ${ }^{18}$, albowiem niezależnie od tego, którego państwa sądy rozpatrują sprawę, umożliwia wydanie jednolitego rozstrzygnięcia i $\mathrm{w}$ ten sposób wzmacnia międzynarodową harmonię rozstrzygnięć ${ }^{19}$. Możliwość uwzględnienia przepisów wymuszających swoje zastosowanie państwa trzeciego sprzyja wzajemnemu zaufaniu pomiędzy poszczególnymi państwami i tym samym współpracy oraz solidarności międzynarodowej, co ma szczególne znaczenie w dobie wzajemnej zależności państw, zwłaszcza w odniesieniu do państw członkowskich $\mathrm{UE}^{20}$. Niekiedy uwzględnienie przepisu wymuszającego swoje zastosowanie państwa trzeciego może również nawet leżeć w interesie państwa, którego sąd rozpatruje sprawę, a ponadto państwo to może mieć uzasadniony interes w tym, aby również jego przepisy były uwzględniane przez sądy innych państw ${ }^{21}$. W każdym jednak przypadku ustalenia wymuszajacego charakteru przepisów państwa trzeciego należy dokonywać w oparciu o analizę funkcjonalna, w ramach której wartościowane są racje i cele, które dany przepis wyraża, a także oceniane konsekwencje, jakie analizowany przepis może wywrzeć na rozpatrywany stosunek prawny ${ }^{22}$.

Przepis art. 9 ust. 3 rozporządzenia Rzym I uzależnia dopuszczenie do głosu rzeczonych przepisów od spełnienia ściśle określonych przesłanek. Zgodnie $\mathrm{z}$ jego treścią charakter przepisów wymuszajacych swoje zastosowanie może zostać przyznany przepisom państwa, w którym ma nastąpić lub nastapiło wykonanie zobowiązań wynikających z umowy, a ponadto jest to dopuszczalne jedynie $\mathrm{w}$ zakresie, $\mathrm{w}$ jakim przepisy te

${ }^{16}$ Zob. M. Wojewoda: Zakres prawa właściwego dla zobowiazań umownych, Kraków 2007 s. 139 i nast.; M.A. Zachariasiewicz: Przepisy..., s. 455-458.

${ }^{17}$ Por. M. Wojewoda: Mandatory Rules in Private International Law. "Maastricht Journal of European and Comparative Law" 2000. Vol, 7, nr 2, s. 212.

${ }^{18}$ Forum shopping jako takie nie można jednak uznać za zjawisko negatywne i niepożądane.

${ }^{19}$ Por. A. Bonomi: Le regime des règles impératives et des lois de police dans le Règlement "Rome I» sur la loi applicable aux contrats. In: Le nouveau règlement européen „Rome I" relatif à la loi applicable aux obligations contractuelles. Red. A. Bonomi, E. Cashin Ritaine, Genève 2008, s. 235.

${ }^{20}$ Por. M.A. Zachariasiewicz: Przepisy..., s. 455.

${ }^{21}$ Por. pkt 88 opinii.

${ }^{22}$ Por. pkt. 74 i 88 opinii. 
powoduja, że wykonanie umowy jest niezgodne z prawem. W związku $\mathrm{z}$ odmiennym brzmieniem od art. 7 ust. 1 konwencji rzymskiej ${ }^{23}$, który wymaga jedynie ścisłego związku stanu faktycznego z prawem państwa trzeciego ${ }^{24}$, oraz mając na uwadze, że rozporządzenie Rzym I nawiąuje do konwencji rzymskiej także w omawianym zakresie, powstają uzasadnione wątpliwości co do interpretacji oraz krytyka uregulowania przyjętego $\mathrm{w}$ tym rozporządzeniu ${ }^{25}$. Krytycznie ocenić należy zwłaszcza brak odniesienia w art. 9 ust. 3 rozporządzenia Rzym I do ścisłego związku pomiędzy przepisem wymuszającym swoje zastosowanie obowiązującym w państwie wykonania zobowiązania umownego a ocenianą kwestią sporną ${ }^{26}$.

\section{Ograniczenie do przepisów państwa, w którym ma nastąpić lub nastąpiło wykonanie zobowiązania}

Autonomicznej wykładni rzeczonego przepisu należy dokonywać w kontekście całościowej regulacji art. 9 rozporządzenia Rzym I dotyczącej przepisów wymuszających swoje zastosowanie. Trybunał trafnie konstatuje, że art. 9 rozporządzenia Rzym I stanowi odstępstwo od zasady swobodnego wyboru przez strony umowy prawa właściwego i jako taki podlega ścisłej wykładni ${ }^{27}$. Dotyczy to zatem również ust. 3 rzeczonego przepisu. Wymóg restrykcyjnej wykładni przemawia więc za ograniczeniem stosowania przepisów wymuszających swoje zastosowanie państwa trzeciego, wyłacznie do przepisów państwa, w którym ma nastąić lub nastąiło wykonanie zobowiązania. Ponadto za taką interpre-

${ }^{23}$ Konwencja o prawie właściwym dla zobowiązań umownych, otwarta do podpisu w Rzymie dnia 19 czerwca 1980 r., Dz.U. UE z 2005 r., C 169, s. 10 i n. wersja polska.

${ }^{24}$ Zob. szerzej na ten temat m.in. B. Fuchs: Statut..., s. 151-161; M. Wojewoda: Zakres..., s. 158-166.

${ }^{25}$ Zob. M.A. Zachariasiewicz: Przepisy..., s. 459-460. Zob. także literature powołaną w przypisie 3 .

${ }^{26}$ Zob. więcej M.A. Zachariasiewicz: Przepisy..., s. 460-461.

${ }^{27}$ Por. pkt. 43 i 44 wyroku. Stwierdzenie to należy jednak doprecyzować w ten sposób, że rzeczony przepis stanowi ogółem odstępstwo od zastosowania prawa właściwego dla umowy, w tym także wyznaczonego na podstawie łączników obiektywnych określonych w rozporządzeniu Rzym I, a nie tylko na podstawie wyboru prawa przez strony; por. W.-H. Roth: Drittstaatliche..., s. 180. 
tacją przemawia również wykładnia historyczna ${ }^{28}$. Jak Trybunał podnosi w uzasadnieniu komentowanego wyroku, pierwotny wniosek Komisji dotyczący art. 9 przewidywał przejętą z konwencji rzymskiej możliwość przyznania skuteczności przepisom wymuszającym swoje zastosowanie państwa trzeciego, z którym dana umowa wykazuje bliski związek, jednak wniosek ten nie został uwzględniony ${ }^{29}$, i zamiast tego ostatecznie zdecydowano się na redakcję tego przepisu wyraźnie odnosząca się do przepisów państwa, w którym ma nastąić lub nastąiło wykonanie zobowiązań wynikających z umowy oraz do kryterium niezgodności wykonania umowy z prawem ${ }^{30}$. Taka redakcja wyraźnie wskazuje, że chodzi o ograniczenie dopuszczalności przyznania skuteczności przepisom wymuszającym swoje zastosowanie państwa trzeciego w stosunku do konwencji rzymskiej ${ }^{31}$. Istotne jest również, co trafnie dostrzega Trybunał, że ograniczenie możliwości stosowania przepisów wymuszających swoje zastosowanie do przepisów prawa państwa wykonania umowy ogranicza zakłócenia systemu norm kolizyjnych wywoływane stosowaniem innych przepisów tego rodzaju niż przepisy państwa sądu rozpoznającego spór, co było też zamiarem ustawodawcy unijnego ${ }^{32}$. Tezę Trybunału potwierdza wreszcie wykładnia celowościowa. Głównym celem rozporządzenia jest zgodnie z jego motywem 16 zapewnienie pewności prawa $\mathrm{w}$ europejskiej przestrzeni sprawiedliwości, w związku z czym normy kolizyjne powinny być w jak największym stopniu przewidywalne. Należy zgodzić się ze stwierdzeniem Trybunału, że możliwość stosowania przepisów wymuszających swoje zastosowanie należących do porządku prawnego państw członkowskich innych niż wyraźnie określone w rozporządzeniu Rzym I, mogłoby utrudnić pełną realizację tego celu, zwiększyłoby bowiem liczbę stosujacych się przepisów wymuszajacych swoje zastosowanie i mogłoby tym samym mieć wpływ na przewidywalność norm materialnych właściwych dla umowy ${ }^{33}$. W kontekście omawianego sporu nie bez znaczenia jest aspekt ochrony pracownika. Trybunał trafnie zauważa, że możliwość stosowania przepisów wymuszających swoje zastosowanie innych niż przepisy wyraźnie określone w rozporządzeniu mogłoby zagrozić zamierzonemu przez art. 8 tego rozporządzenia celowi zagwarantowania, w zakresie, w jakim to możliwe, poszanowania prze-

${ }^{28}$ Zob. co do perypetii związanych z omawianym przepisem w toku prac nad rozporządzeniem Rzym I M.A. Zachariasiewicz: Przepisy..., s. 468-459.

${ }^{29}$ Por. pkt 45 wyroku.

${ }^{30}$ Zob. więcej na ten temat A. Helmer: Die Methodik..., s. 46 i n.; M. Wojewoda: Zakres..., s. 134 i n.

${ }^{31}$ Por. pkt 82 opinii.

${ }^{32}$ Por. pkt 45 wyroku.

${ }^{33}$ Por. pkt. 46 i 47 wyroku. 
pisów zapewniających ochronę pracownika przewidzianych przez prawo państwa, w którym pracownik ten wykonuje swoją działalność zawodo$\mathrm{wa}^{34}$. W świetle powyższych względów uznać należy, że wyszczególnienie w art. 9 rozporządzenia Rzym I przepisów wymuszających swoje zastosowanie ma charakter wyczerpujący ${ }^{35} \mathrm{i}$ w związku z tym art. 9 rozporządzenia Rzym I należy interpretować w ten sposób, że wyklucza on, by sąd orzekający mógł zastosować w charakterze norm prawnych przepisy wymuszające swoje zastosowanie inne niż tego rodzaju przepisy państwa sądu lub państwa, w którym ma nastąpić lub nastąpiło wykonanie zobowiazań wynikajacych z umowy ${ }^{36}$. Oznacza to słusznie, że w świetle art. 9 ust. 3 rozporządzenia Rzym I sąd orzekajacy może przyznać skuteczność przepisom wymuszającym swoje zastosowanie wyłącznie państwa, w którym umowa ma być lub została wykonana. Zgodzić należy się z teza Trybunału, że zasada lojalnej współpracy ustanowiona w art. 4 ust. 3 TUE nie zezwala sądowi odsyłającemu na pominięcie zawartego w art. 9 rozporządzenia Rzym I wyczerpujacego charakteru wyliczenia przepisów wymuszających swoje zastosowanie ${ }^{37}$. Zatem również z tego względu nie jest możliwe bezpośrednie uwzględnienie przepisów wymuszajacych swoje zastosowanie państwa trzeciego niezależnie od prawa właściwego dla umowy wyznaczonego zgodnie z rozporządzeniem Rzym I, nawet jeżeli prawo krajowe taką możliwość przewiduje.

Trybunał nie dokonał wprawdzie wykładni pojęcia „państwa, w którym ma nastąić lub nastąpiło wykonanie zobowiązania”. Warto jednak zwrócić uwagę na kilka wskazówek użytecznych przy interpretacji tego pojęcia, które można odczytać z rzeczonego przepisu. Po pierwsze, chodzi tu bowiem, jak wyraźnie stanowi rzeczony przepis, o określenie ogółem państwa, na terytorium którego zobowiązanie umowne jest wykonywane lub ma zostać wykonane, nie zaś o ustalenie konkretnego miejsca $\mathrm{w}$ danym państwie, a więc znaczenie ma nie tylko o materialne (faktyczne) wykonywanie przez stronę umowy czynności w określonym miejscu geograficznym, lecz także powiązanie ze sferą władczą danego państwa i z jego systemem prawnym ${ }^{38}$. Po drugie, nie chodzi również o wykonanie zobowiązania polegającego wyłącznie na spełnieniu „świadczenia charakterystycznego" stosunku umownego, lecz można wziąć pod uwa-

${ }^{34}$ Por. pkt 48 wyroku.

${ }^{35}$ Por. F. Berner: Kollisionsrecht im Spannungsfeld von Kollisionsnormen, Hoheitsinteressen und wohlerworbenen Rechten, Tübingen 2017, s. 171, 178-179; M.A. Zachariasiewicz: Objaśnienia do art. 9 Rzym I, s. 716.

${ }^{36}$ Por. pkt. 49 i 50 wyroku.

${ }^{37}$ Por. pkt 54 wyroku.

${ }^{38}$ Por. M.A. Zachariasiewicz: Objaśnienia do art. 9 Rzym I, s. 716. 
gę wykonanie jakiegokolwiek zobowiązania wynikajacego $\mathrm{z}$ umowy ${ }^{39}$. Wreszcie po trzecie, nie musi tu chodzić wyłącznie o zobowiazanie, które zostało wprost zdefiniowane przez strony w umowie, albowiem prawo, któremu dana umowa podlega, może inaczej kształtować lub uzupełniać zobowiąania stron w stosunku do tego, co strony wprost postanowiły ${ }^{40}$.

Interpretacja art. 9 ust. 3 rozporządzenia Rzym I dokonana przez Trybunał oznacza, w konsekwencji, że kolizyjnoprawna dopuszczalność stosowania przepisów wymuszających swoje zastosowanie państwa forum jest nieograniczona, kolizyjnoprawne uwzględnienie takich przepisów państwa trzeciego jest zaś możliwe jedynie w ściśle określonych sytuacjach. Taki kolizyjnoprawny mechanizm stosowania przepisów wymuszajacych swoje zastosowanie przyjęty w rozporządzeniu Rzym I wydaje się na chwilę obecna słusznym rozwiązaniem i wpisuje się $\mathrm{w}$ koncepcje przyjmowane $\mathrm{w}$ tym zakresie $\mathrm{w}$ poszczególnych porządkach krajowych, tak jak ma to przykładowo miejsce w prawie polskim i angielskim $^{41}$.

\section{Teoria faktu jako unijna metoda dopuszczania do głosu przepisów wymuszających swoje zastosowanie państwa trzeciego w zakresie umownych stosunków obligacyjnych}

Trybunał wyjaśnił, w jaki sposób na podstawie art. 9 ust. 3 rozporządzenia Rzym I przepisy wymuszajace swoje zastosowanie państwa, w którym ma nastapić lub nastąpiło wykonanie umowy, dochodzą do głosu. W tym względzie, jak wspomniano, oparł się na teorii faktu, co należy uznać za słuszne rozwiąanie. Za taką koncepcją przemawia wiele przekonujących argumentów.

Przepisy chroniace interesy publiczne państwa trzeciego, takie jak organizacja polityczna, społeczna lub gospodarcza tego państwa mające charakter wymuszający swoje zastosowanie mogą dojść do głosu nie tylko w drodze kolizyjnoprawnego mechanizmu przepisów wymuszajacych swoje zastosowanie (bezpośrednio), ale również wtedy gdy prawo wska-

${ }^{39}$ Ibidem.

${ }^{40}$ Por. pkt. 91-94 opinii.

${ }^{41}$ Zob. M.A. Zachariasiewicz: Przepisy..., s. 459. Autorka ta jednak wskazuje, że takie rozwiązanie jest pozbawione na gruncie prawa angielskiego solidnego i teoretycznego spójnego uzasadnienia, ibidem. 
zane jako właściwe pozwala na uwzględnienie takich przepisów w charakterze okoliczności faktycznej (pośrednio), na co również wskazuje się $\mathrm{w}$ polskiej doktrynie prawa prywatnego międzynarodowego ${ }^{42}$. Wówczas problem przyznawania takiego charakteru i kolizyjnej dopuszczalności stosowania takich przepisów przez są rozpoznajacy spór w zasadzie nie powstaje, gdyż sad ten uwzględnia te przepisy $\mathrm{w}$ ramach zastosowania prawa właściwego zgodnie z zasadami dotyczącymi uwzględniania przepisów prawa obcego jako okoliczności faktycznej ${ }^{43}$. Jeżeli w ramach stosowania prawa wskazanego i na podstawie tego prawa dochodzi do uwzględnienia obcego przepisu wymuszającego swoje zastosowanie, to mamy wówczas do czynienia ze stosowaniem wyłacznie legis causae i w żadnym wypadku nie jest to odstępstwo od stosowania legis causae $e^{44}$.

Normy kolizyjne prawa prywatnego międzynarodowego zasadniczo nie moga sprzeciwiać się stosowaniu tego rodzaju zasad jako elementu prawa właściwego, albowiem jego rola jest jedynie wyznaczenie tego prawa, a nie regulacja zasad stosowania poszczególnych norm merytorycznych tego prawa. Takim przepisem pozwalającym na uwzględnienie przepisów wymuszających państwa trzeciego jako okoliczności faktycznej jest, jak wynika z wyjaśnień sądu odsyłającego ${ }^{45}$, oparty na Schuldstatuttheorie ${ }^{46}$ przepis $§ 241$ ust. 2 niemieckiego kodeksu cywilnego (Bür-

${ }^{42}$ Por. W. Popiołek: Wykonanie zobowiazania umownego a prawo miejsca wykonania: zagadnienia kolizyjnoprawne, Katowice 1989, s. 163 i nast.; M. Mataczyński: Przepisy..., s. 181 i nast.

${ }^{43}$ Gwoli ścisłości należy przyznać pełną rację rzecznikowi generalnemu M. Szpunarowi, że praktyczna różnica pomiędzy bezpośrednim kolizyjnoprawnym zastosowaniem a materialnoprawnym uwzględnieniem obcego przepisu wymuszającego swoje zastosowanie jest niemal niezauważalna, a różnica pojawia się jedynie w odniesieniu do doktrynalnego uzasadnienia takiego rozróżnienia; por. pkt 101 opinii. Rozróżnienie to jest jednak istotne nie tylko z teoretycznego, ale również z praktycznego punktu widzenia, czego dowodzi przedmiotowa sprawa. W toku postępowania przed Trybunałem Komisja zaproponowała bowiem wykładnię spornego art. 9 ust. 3, w świetle której wyłączona jest jakakolwiek inna możliwość niż kolizyjnoprawna uwzględnienia przepisów wymuszających swoje zastosowanie państwa trzeciego (por. pkt 101 opinii). W związku z tym również odniesienie się Trybunału do dopuszczalności materialnoprawnego uwzględniania tego rodzaju przepisów na podstawie legis causae w świetle ww. przepisu jest w pełni uzasadnione i zrozumiałe.

${ }^{44}$ Por. D. Martiny: Art. 9 Rom I-VO, s. 554 i n.; por. pkt 102 i 106 opinii.

${ }^{45}$ Zob. pkt 97 opinii.

${ }_{46}$ Teoria ta pozwala na pośrednie uwzględnienie przepisów „imperatywnych” jako elementu faktycznego w ramach zastosowania statutu kontraktowego, który rozstrzyga o przesłankach i skutkach takiego uwzględnienia. W piśmiennictwie wskazuje się, że teoria ta stała się znana większości państw członkowskich UE już pod rządami konwencji rzymskiej i znajduje wiele przekonujaccych argumentów za jej zastosowaniem; por. W.-H. Roth: Drittstaatliche..., s. 182. Zob. także J. Harris: Mandatory Rules and Public policy under the Rome I Regulation, w: Rome I Regulation, The Law Applicab- 
gerliches Gestetzbuch) ${ }^{47}$. Zgodnie z brzmieniem tego przepisu, stosunek zobowiązaniowy może, w zależności od jego treści, nakładać na każdą ze stron obowiązek uwzględniania praw, dóbr prawnych i interesów drugiej strony. Podobne przepisy operujące zwrotami niedookreślonymi sa zawarte w innych porządkach prawnych. Służą one zapewnieniu sądom odpowiedniej swobody decyzyjnej. Może tu chodzić również o klauzule generalne prawa polskiego, takie jak „dobre obyczaje”, „dobra wiara” czy „zasady współżycia społecznego”. Nie można wykluczyć, że w ramach stosowania takich przepisów będą brane pod uwagę jako okoliczność faktyczna, w oparciu o różne uzasadnienia dogmatyczne i doktrynalne, regulacje prawne majace charakter przepisów wymuszających swoje zastosowanie obowiąujące w innych państwach niż państwo forum lub legis causae. Dotyczy to również prawa polskiego, które jednak, o ile wiadomo, takiej możliwości jak dotąd nie dopuszcza.

Podkreślić należy, że rozporządzenie Rzym I, w tym art. 9 dotyczący przepisów wymuszających swoje zastosowanie, ustanawia jednolite normy (kolizyjne) prawa prywatnego międzynarodowego $\mathrm{w}$ odniesieniu do zobowiązań umownych, a nie normy materialne prawa umów. W zakresie zatem, w jakim właściwe normy merytoryczne przewiduja, że sąd uwzględnia lub może uwzględnić jako okoliczność faktyczna przepisy wymuszające swoje zastosowanie należące do porządku prawnego państwa innego niż państwo sądu lub państwo wykonania świadczeń wynikajacych z umowy, rozporządzenie to nie może sprzeciwiać się uwzględnieniu przez sąd forum tego rodzaju przepisów jako okoliczności faktycznej ${ }^{48}$. W przeciwnym razie oznaczałoby to, że rozporządzenie Rzym I nie tylko wyznacza prawo właściwe dla stosunku umownego, lecz także może ingerować w samo stosowanie prawa wskazanego jako właściwe do merytorycznej oceny danego sporu ${ }^{49}$, co jest nie do pogodzenia z kolizyjnoprawną

le to Contractual Obligations in Europe. Red. F. Ferrari, S. Leible, Munich 2009, s. 302 i n. Warto zwrócić uwagę, iż w prawie niemieckim do dnia 17 grudnia 2009 r. obowiązywał przepis $§ 34$ ustawy wprowadzającej kodeks cywilny (Einführungsgesetz zum Bürgerlichen Gesetzbuche, RGBl. z 1896 r., s. 609 i n. ze zm.). Przepis ten odnoszaccy się do przepisów wymuszających swoje zastosowanie prawa niemieckiego stanowił, że „[n]iniejszy podrozdział nie narusza zastosowania przepisów prawa niemieckiego, które bezwzględnie regulują stan faktyczny niezależnie od prawa właściwego dla umowy". Jak wskazuje rzecznik generalny w swojej opinii, w świetle orzecznictwa oraz doktryny niemieckiej przepis ten nie wykluczał zastosowania wymuszających swoje zastosowanie przepisów państwa trzeciego, a przynajmniej uwzględnienia takich przepisów jako okoliczności faktycznej w ramach stosowania przepisów prawa właściwego, zawierających zwroty niedookreślone (,,ausfüllungsbedürftige Rechtsnormen”); por. pkt 11 opinii.

${ }^{47}$ RGBl. z 1896 r., s. 195 i n., ze zm.

${ }^{48}$ Por. M. Thorn: Forumfremde..., s. 305.

${ }^{49}$ Por. pkt. $103-105$ opinii. 
natura tego rozporządzenia. Takie uwzględnienie przepisu wymuszającego swoje zastosowanie mieści się zatem poza zakresem stosowania rozporządzenia Rzym $\mathrm{I}^{50}$. Artykuł 9 ust. 3 rozporządzenia nie może więc jako norma kolizyjna ingerować w sposób stosowania prawa wskazanego jako właściwe ${ }^{51}$. Słusznie zatem Trybunał stwierdza w konkluzji, że art. 9 ust. 3 rozporządzenia Rzym I nie stoi na przeszkodzie uwzględnieniu jako okoliczności faktycznej przepisów wymuszających swoje zastosowanie państwa innego niż państwo sądu lub państwo, w którym ma nastapić lub nastąpiło wykonanie zobowiązań wynikających z umowy, $\mathrm{w}$ zakresie, $\mathrm{w}$ jakim przewiduje to norma materialna prawa właściwego dla umowy na mocy przepisów tegoż rozporządzenia ${ }^{52}$.

Powyższego wniosku nie może podważać zasada lojalnej współpracy określona w art.4 ust. 3 TUE, skoro stosowanie przepisów wymuszajacych swoje zastosowanie w charakterze okoliczności faktycznej odbywa się na podstawie prawa właściwego wskazanego na podstawie aktu prawa unijnego. W glosowanym sporze nie bez znaczenia jest również $\mathrm{w}$ tym kontekście fakt, iż brane pod uwagę w charakterze przepisów wymuszajacych swoje zastosowanie państwa trzeciego przepisy greckie zostały przyjęte $\mathrm{w}$ celu wywiązania się z obowiązków wynikających z członkostwa w Unii ${ }^{53}$.

W tym miejscu nasuwa się spostrzeżenie, którego nie można pominać, że z jednej strony Trybunał przypisuje istotne znaczenie celowi przewidywalności i pewności prawa na płaszczyźnie kolizyjnej, która uzasadnia ograniczenie dopuszczalności bezpośredniego stosowania przepisów wymuszających swoje zastosowanie państwa trzeciego, natomiast $\mathrm{w}$ uzasadnieniu praktycznie nie odnosi się do tych celów w odniesieniu do materialnoprawnego uwzględnienia tych przepisów jako okoliczności faktycznej. Trudno nie dostrzec tutaj pewnej sprzeczności, tym bardziej, że różnica między kolizyjnoprawnym zastosowaniem przepisów wymuszajacych swoje zastosowanie i materialnoprawnym uwzględnieniem takich przepisów może być niemal niezauważalna ${ }^{54}$, zwłaszcza dla praktyki. Wydaje się jednak, iż takie zróżnicowanie można uzasadnić jednak odmiennymi celami bezpośredniego stosowania przepisów wymuszających swoje zastosowanie i pośredniego materialnoprawnego ich uwzględnienia jako okoliczności faktycznej. W pierwszym przypadku

${ }^{50}$ Por. pkt 102 opinii.

${ }^{51}$ Por. M.A. Zachariasiewicz: Objaśnienia do art. 9 Rzym I, s. 717.

${ }^{52}$ Por. pkt 52 wyroku.

${ }^{53}$ Słusznie zwraca uwagę rzecznik generalny w swojej opinii, że podejmując decyzję o ewentualnym przyznaniu skuteczności takim przepisom w oparciu o art. 9 ust. 3 rozporządzenia Rzym I, sąd krajowy powinien uwzględnić tę okoliczność; por. pkt 126 opinii.

${ }^{54}$ Por. W.-H. Roth: Drittstaatliche..., s. 180, 183. Zob. także uwagi w przypisie 44. 
chodzi o przede wszystkim o interesy porządkowe państwa, natomiast $\mathrm{w}$ drugim przypadku o przede wszystkim o interesy stron i zachowanie równowagi będacej wyrazem sprawiedliwości kontraktowej w konkretnym przypadku ${ }^{55}$.

\section{Uwagi końcowe}

Zakreślona w interpretacji Trybunału dopuszczalność i metoda stosowania przepisów majaccych charakter wymuszajacy swoje zastosowanie państwa trzeciego nie oznacza automatyzmu, co dotyczy w równej mierze mechanizmu kolizyjnego, jak i materialnego uwzględniania takich przepisów jako okoliczności faktycznej. W każdym przypadku sąd rozpatrujący sprawę dysponujący w tym zakresie dużym zakresem uprawnień dyskrecjonalnych powinien wydać z uwzględnieniem takich przepisów sprawiedliwe rozstrzygnięcie uwzględniajace słuszne interesy stron, a także interesy państw, których prawo oddziałuje na dany stosunek prawny ${ }^{56}$.

Na koniec wypada jeszcze zasygnalizować, że komentowane orzeczenie nie wyjaśnia wszystkich wątpliwości interpretacyjnych dotyczących przepisu art. 9 ust. 3 rozporządzenia Rzym I. Rzecznik generalny trafnie zwraca uwage w swojej opinii ${ }^{57}$, podobnie jak doktryna ${ }^{58}$, że wątpliwości te wiążą choćby z faktem, że w odniesieniu do przepisów wymuszających swoje zastosowanie państwa forum art. 9 ust. 2 rozporządzenia Rzym I stanowi o ich „stosowaniu”, natomiast w odniesieniu do takich przepisów państwa trzeciego art. 9 ust. 3 tego rozporządzenia stanowi o przyznaniu im „skuteczności” ${ }^{9}$, a ponadto nie jest również jasne, w jakim zakresie prawo Unii może zakazywać stosowania konkretnych przepisów wymuszajacych swoje zastosowanie, ograniczać to stosowanie lub nakazywać je definiując takie przepisy i określając warunku dopuszczalności

\footnotetext{
${ }^{55}$ Por. W.-H. Roth: Drittstaatliche..., s. $183-184$.

${ }^{56}$ Por. pkt 109 opinii.

${ }^{57}$ Por. pkt 83 opinii.

${ }^{58}$ Por. M. Thorn: Forumfremde..., s. 302.

59 Tytułem przykładu wskazać można, iż w doktrynie niemieckiej podnosi się, że materialnoprawne uwzględnienie obcych przepisów jest objęte zakresem pojęcia „przyznania skuteczności” w rozumieniu art. 9 ust. 3 rozporządzenia Rzym I, a więc również podlega ograniczeniom wynikającym z tego przepisu, zob. D. Martiny: Art. 9 Rom I-VO, s. 554 i nast.; O. Remien: Art. 9 ROM I-VO. In: Bürgerliches Gesetzbuch. Kommentar, Hrsg. H. Prütting, G. Wegen, G. Weinreich, 2015, s. 3359.
} 
ich stosowania, tak jak to czyni art. 9 rozporządzenia Rzym I. W szczególności powstaje wówczas pytanie, w jakim zakresie prawo krajowe może uzupełniać regulację unijną. W doktrynie słusznie podnosi się, że wątpliwości budzi również zwrot „wykonanie umowy [...] niezgodne z prawem" ${ }^{\circ}$. Wyjaśnić wszystkie te wątpliwości w sposób wiążący władny jest jedynie Trybunał i możliwe, że pojawi się okazja do doprecyzowania jego orzecznictwa dotyczącego art. 9 ust. 3 rozporządzenia Rzym I.

${ }^{60}$ Zob. w tym względzie M.A. Zachariasiewicz: Przepisy..., s. 460. 